Supplement of Biogeosciences, 14, 5403-5424, 2017

https://doi.org/10.5194/bg-14-5403-2017-supplement

(C) Author(s) 2017. This work is distributed under

the Creative Commons Attribution 3.0 License.

(c) (1)

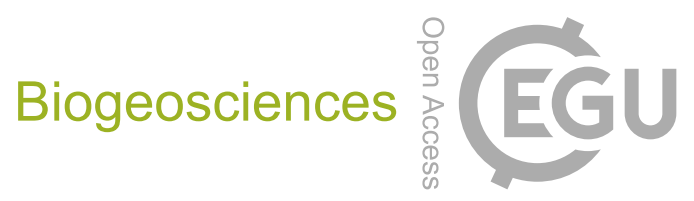

Supplement of

\title{
Hydration status and diurnal trophic interactions shape microbial community function in desert biocrusts
}

Minsu Kim and Dani Or

Correspondence to: Minsu Kim (minsu.kim@usys.ethz.ch)

The copyright of individual parts of the supplement might differ from the CC BY 3.0 License. 


\section{S1 Biocrust temperature distribution and dynamics}

We implemented the heat equation to calculate temperature gradients within the biocrust and daily variations (in the absence of fluid motion):

$c_{v}(\vec{r}) \frac{\partial T(\vec{r}, t)}{\partial t}=\nabla \cdot(\lambda(\vec{r}) \nabla T(\vec{r}, t))$

5 where $\rho_{s}$ and $c_{s}$ are the density of soil and the specific heat capacity per unit mass, respectively. From the volume fractions and densities of solid, water, and gas, the soil volumetric heat capacity can be written:

$c_{v}(\vec{r})=\rho_{s} \theta_{s}(\vec{r}) c_{s}^{s}+\rho_{w} \theta_{w}(\vec{r}) c_{s}^{w}+\rho_{g} \theta_{g}(\vec{r}) c_{s}^{g}$,

where $s, w$, and $g$ denote soil grains (solid), water, and gas fractions. We assume that the effective thermal conductivity of a patch, $\lambda$ is given as a harmonic mean of three conductivities, $\lambda_{s}, \lambda_{w}$, and $\lambda_{g}$ from different phases.

$10 \lambda(\vec{r})=\left(\frac{\theta_{s}(\vec{r})}{\lambda_{s}}+\frac{\theta_{w}(\vec{r})}{\lambda_{w}}+\frac{\theta_{g}(\vec{r})}{\lambda_{g}}\right)^{-1}$

In the model, the proportion of organic matter (such as EPS, or microbial cells) are ignored for the thermal properties.

\section{S2 Modelling of chemical reactions within biocrusts}

Two main chemical processes are included in the biocrust model; liquid and gas phase partitioning from Henry's law and local acid-base reactions within soil pore water. These chemical processes are very fast compared with microbial or diffusion processes, therefore we numerically implemented the results of chemical reactions (such as $\mathrm{pH}$ estimation) as boundary conditions for reaction diffusion equations (every time step it calculates the new equilibrium solution within a patch).

Firstly, the temperature dependent Henry's law is given as following:

$C^{l^{*}}=H_{c c}^{\Theta} e^{-\frac{\Delta_{\text {soln } H}}{R}\left(\frac{1}{T}-\frac{1}{T^{\Theta}}\right)} C^{g *}$, 
where $H_{c c} \equiv k_{H} R T$ is the dimensionless Henry's constant, the superscript $\Theta$ indicates the standard temperature $\left(T^{\Theta}=\right.$ $298.15 \mathrm{~K}) . \Delta_{\text {soln }} H$ is the enthalpy of solution and $R$ is the gas constant. In Table S1, values used for Henry's law constants are given Sander (1999) together with the partial pressure in the atmosphere. The partial pressure of each element in the atmosphere was set to be constant in the model.

\begin{tabular}{ccccc}
\hline substance & $k_{H}^{\ominus}[\mathrm{M} / \mathrm{atm}]$ & $-\frac{\Delta_{\text {soln } H}}{R}[\mathrm{~K}]$ & partial pressure [atm] & reference \\
\hline \hline $\mathrm{O}_{2}$ & $1.3 \times 10^{-3}$ & 1500 & 0.2095 & - \\
$\mathrm{CO}_{2}$ & $3.5 \times 10^{-2}$ & 2400 & $383 \times 10^{-6}$ & - \\
$\mathrm{NH}_{3}$ & $6.1 \times 10^{1}$ & 4200 & $5 \times 10^{-9}$ & assumed $^{a}$ \\
$\mathrm{HONO}$ & $5 \times 10^{1}$ & 4900 & $10^{-9}$ & ${\text { Su et al. }(2011)^{b}}$ \\
$\mathrm{~N}_{2} \mathrm{O}$ & $2.5 \times 10^{-2}$ & 2600 & $5 \times 10^{-7}$ & assumed $^{c}$ \\
\hline
\end{tabular}

Table S1. Henry's law constants of gaseous elements Sander (1999) and partial pressure in the atmosphere.

${ }^{a}$ The atmospheric level of $\mathrm{NH}_{3}$ varies depending on the time of the day, season and regions. Generally it is given in a range of $1 \sim 10$ ppb.

${ }^{b}$ The gas phase concentration of HONO ranges over several orders of magnitude for different regions, $0.1 \sim 600$ ppb. In this model, we have chosen the field measurement from semiarid pine forest $\mathrm{Su}$ et al. (2011).

${ }^{c}$ The atmospheric level of $\mathrm{N}_{2} \mathrm{O}$ is in a range of $100 \sim 1000 \mathrm{ppb}$.

Secondly, acid-base reactions for $\mathrm{pH}$ estimation were described as near-equilibrium kinetics with an assumption of local charge neutrality. For instance, the kinetics of the ammonium concentration was written as an ordinary differential equation,

$$
\frac{d C_{\mathrm{NH}_{4}}^{+}}{d t}=-k_{4}\left(C_{\mathrm{NH}_{4}}{ }^{+}-C_{\mathrm{NH}_{4}}^{*}\right)=-k_{4}\left(C_{\mathrm{NH}_{4}}{ }^{+}-\frac{C_{\mathrm{NH}_{3}} C_{\mathrm{H}^{+}}}{K_{A}}\right)
$$

where the equilibrium concentration of ammonium, $C_{\mathrm{NH}_{4}{ }^{+}}^{*}$, which will be reached with the rate $k_{4} \cdot C_{\mathrm{NH}_{4}}^{*}{ }^{+}$can be calculated with the acid-base equilibrium with ammonia, $\frac{C_{\mathrm{NH}_{3} \mathrm{C}_{\mathrm{H}}^{+}}}{K_{A}} . K_{A}$ is the ammonia dissociation constant, which depends on the temperature and the ionic strength. Here, the concentration of protons, $C_{\mathrm{H}^{+}}$, holds the local charge neutrality at local scale by satisfying the relation;

$C_{\mathrm{H}^{+}}+C_{\mathrm{NH}_{4}}{ }^{+}+2 C_{\mathrm{Ca}^{2+}}-C_{\mathrm{OH}^{-}}-C_{\mathrm{HCO}_{3}{ }^{-}}-2 C_{\mathrm{CO}_{3}{ }^{2-}}-2 C_{\mathrm{NO}_{2}{ }^{-}}-C_{\mathrm{NO}_{3}{ }^{-}}+C_{Z}=0$

where $C_{Z}$ is the net concentration of anion and cation that are non-reactive in the model (unknown ions that regulate the soil $\mathrm{pH}$ in the model). Furthermore, nitrate, $\mathrm{NO}_{3}{ }^{-}$, is also included in the $\mathrm{pH}$ calculation for charge balancing although it does not participate for acid dissociation. Therefore, including the estimation of soil pore water $\mathrm{pH}$, we solved 10 coupled differential algebraic equations at each patch (chemical information of local soil pore water) for the chemical reaction dynamics and applied the solution as boundary conditions every time step in the model. All the chemical reactions and rate constants used in the model are given in Table S2 and S3. 


\begin{tabular}{|c|c|c|c|}
\hline process & reaction & rate constant $k\left[\right.$ day $\left.^{-1}\right]$ & reaction ID \\
\hline Autoprotolysis of $\mathrm{H}_{2} \mathrm{O}$ & $\mathrm{H}_{2} \mathrm{O} \rightleftharpoons \mathrm{OH}^{-}+\mathrm{H}^{+}$ & implemented as equilibrium & $\mathrm{R}(1)$ \\
\hline Hydration of $\mathrm{CO}_{2}$ & $\mathrm{CO}_{2}(\mathrm{aq})+\mathrm{H}_{2} \mathrm{O} \rightleftharpoons \mathrm{HCO}_{3}^{-}+\mathrm{H}^{+}$ & $k_{2}=2221$ & $\mathrm{R}(2)$ \\
\hline Dissociation of $\mathrm{HCO}_{3}^{-}$ & $\mathrm{HCO}_{3}^{-} \rightleftharpoons \mathrm{CO}_{3}^{2-}+\mathrm{H}^{+}$ & $k_{3}=10^{10}$ (very fast reaction) & $\mathrm{R}(3)$ \\
\hline Dissociation of $\mathrm{NH}_{3}$ & $\mathrm{NH}_{4}^{+} \rightleftharpoons \mathrm{NH}_{3}(\mathrm{aq})+\mathrm{H}^{+}$ & $k_{4}=10^{10}$ (very fast reaction) & $\mathrm{R}(4)$ \\
\hline Dissociation of $\mathrm{HNO}_{2}$ & $\mathrm{HNO}_{2}(\mathrm{aq}) \rightleftharpoons \mathrm{NO}_{2}^{-}+\mathrm{H}^{+}$ & $k_{5}=10^{10}$ (very fast reaction) & $\mathrm{R}(5)$ \\
\hline Solubility of $\mathrm{CaCO}_{3}$ & $\mathrm{CaCO}_{3}(\mathrm{aq}) \rightleftharpoons \mathrm{Ca}^{2+}+\mathrm{CO}_{3}{ }^{2-}$ & $k_{6}=10^{10}$ (very fast reaction) & $\mathrm{R}(6)$ \\
\hline
\end{tabular}

Table S2. Acid-base reactions considered in the model.

\begin{tabular}{|c|c|c|c|c|c|c|c|c|c|c|c|}
\hline reaction ID & $\mathrm{C}_{\mathrm{CO}_{2}}$ & $C_{\mathrm{HCO}_{3}}^{-}$ & $C_{\mathrm{CO}_{3}{ }^{2-}}$ & $C_{\mathrm{NH}_{3}}$ & $C_{\mathrm{NH}_{4}}^{+}$ & $\mathrm{C}_{\mathrm{HNO}_{2}}$ & $C_{\mathrm{NO}_{2}}^{-}$ & $\mathrm{C}_{\mathrm{CaCO}_{3}}$ & $C_{\mathrm{Ca}^{2+}}$ & Rate & $K_{a}^{*}$ \\
\hline $\mathrm{R}(1)$ & & & & & & & & & & $C_{\mathrm{H}^{+}} C_{\mathrm{OH}^{-}}=K_{w}$ & $K_{w}$ \\
\hline $\mathrm{R}(2)$ & -1 & +1 & & & & & & & & $k_{2}\left(C_{\mathrm{CO}_{2}}-\frac{{ }_{\mathrm{HCO}_{3}}{ }^{-C_{\mathrm{H}^{+}}}}{K_{1 C}}\right)$ & $K_{1 C}$ \\
\hline $\mathrm{R}(3)$ & & -1 & +1 & & & & & & & $k_{3}\left(C_{\mathrm{HCO}_{3}}{ }^{-}-\frac{{ }^{C} \mathrm{CO}_{3}{ }^{2-} C_{\mathrm{H}^{+}}}{K_{2 C}}\right.$ & $K_{2 C}$ \\
\hline $\mathrm{R}(4)$ & & & & +1 & -1 & & & & & $k_{4}\left(C_{\mathrm{NH}_{4}}+-\frac{C_{\mathrm{NH}_{3}} C_{\mathrm{H}^{+}}}{K_{A}}\right)$ & $K_{A}$ \\
\hline $\mathrm{R}(5)$ & & & & & & -1 & +1 & & & $k_{5}\left(C_{\mathrm{HNO}_{2}}-\frac{\mathrm{NO}_{2}{ }^{-} \mathrm{H}^{+}}{K_{N}}\right.$ & $K_{N}$ \\
\hline $\mathrm{R}(6)$ & & & +1 & & & & & -1 & +1 & $k_{6}\left(C_{\mathrm{CaCO}_{3}}-\frac{{ }^{C} \mathrm{Ca}^{2+}{ }^{C} \mathrm{CO}_{3}{ }^{2-}}{K_{s p}}\right.$ & $K_{s p}$ \\
\hline
\end{tabular}

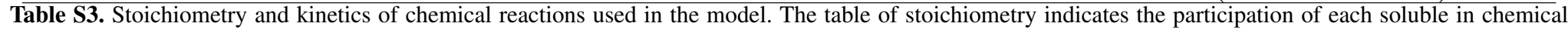
reactions and rate describes the near equilibrium kinetics used in the model. Concentrations of solubles are denoted as $C_{\text {substance }}$ with a unit of [M].

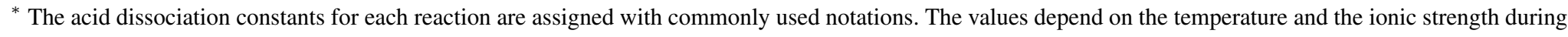
the dynamics following Table S4 and Equation (S7). 
As the desert biocrust model includes the large variation of temperature, acid dissociation constants, $K_{a}$ (or $\mathrm{p} K_{a}=-\log _{10} K_{a}$ ) are also given as a function of temperature Plummer and Busenberg (1982); Buhr and Miller (1983); Ebrahimi et al. (2003). Used expressions for the temperature dependency are summarised in Table S4. Including the temperature dependency of acid dissociation and ionic interaction in the solution, the equilibrium dissociation constants for partitioning chemical species can

5 be calculated at the given temperature and ionic strength Buhr and Miller (1983); Yang (2011). By using the extended DebyeHückel equation, the negative logarithm of activity coefficients can be written as

$p \gamma=\frac{G \zeta^{2} \sqrt{I}}{1+a B \sqrt{I}}$,

where $\zeta$ and $I$ are ionic valency and ionic strength of the solution, $a$ is the effective diameter of the ion in angstrom $(a=$ $\left.4\left(\mathrm{HCO}_{3}{ }^{-}\right) ; 4.5\left(\mathrm{CO}_{3}{ }^{2-}\right) ; 2.5\left(\mathrm{NH}_{4}{ }^{+}\right) ; 9\left(\mathrm{H}^{+}\right) ; 3\left(\mathrm{NO}_{2}{ }^{-}\right) ; 6\left(\mathrm{Ca}^{2+}\right)\right) . G$, and $B$ are temperature dependent constants Buhr and

10 Miller (1983).

$\begin{aligned} G & =1.825 \times 10^{6}(\epsilon T)^{-1.5} \\ B & =50.3(\epsilon T)^{-0.5}\end{aligned}$

where $\epsilon=87.74-0.40008(T-273.15)+9.398 \times 10^{-4}(T-273.15)^{2}-1.41 \times 10^{-6}(T-273.15)^{3}$ is the temperature correction term. With the correction from the activity coefficient, the equilibrium dissociation (protonation) constants for chemical reactions can be calculated as following:

$$
\begin{aligned}
& K_{1 C}=10^{-p K_{1 C}(T)+p \gamma_{\mathrm{H}^{+}}+p \gamma_{\mathrm{HCO}_{3}}{ }^{-}}
\end{aligned}
$$

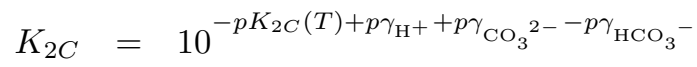

$$
\begin{aligned}
& K_{A}=10^{-p K_{A}(T)+p \gamma_{\mathrm{H}^{+}}-p \gamma_{\mathrm{NH}_{4}}{ }^{+}} \\
& K_{N}=10^{-p K_{N}(T)+p \gamma_{\mathrm{H}^{+}+p \gamma_{\mathrm{NO}_{2}}}{ }^{-}}
\end{aligned}
$$

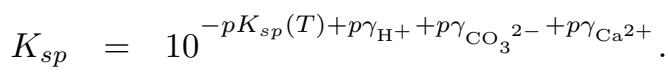

These values are used in chemical kinetics described in Table S3.

\begin{tabular}{clc}
\hline reaction ID & temperature dependent $\mathrm{p} K_{a}$ & reference \\
\hline \hline $\mathrm{R}(1)$ & $140.932-13446 / T-22.4773 \ln T$ & Ebrahimi et al. (2003) \\
$\mathrm{R}(2)$ & $3404.71 / T-14.8435+0.032786 T$ & Buhr and Miller (1983) \\
$\mathrm{R}(3)$ & $2902.39 / T-6.498+0.02379 T$ & Buhr and Miller (1983) \\
$\mathrm{R}(4)$ & $2835.76 / T-0.6322+0.001225 T$ & Buhr and Miller (1983) \\
$\mathrm{R}(5)$ & $-\log _{10}\left(5.6 \times 10^{-4} e^{171217(1 / T-1 / 298.15)}\right)$ & Su et al. (2011) \\
$\mathrm{R}(6)$ & $171.90+0.07799 T-2839.3 / T-31.093 \ln T$ & Plummer and Busenberg (1982) $^{a}$
\end{tabular}

Table S4. Temperature dependency of acid dissociation constants used in the model.

${ }^{a}$ Phenomenological expressions for the temperature dependency of HONO dissociation are scarce. Following Su et al. (2011), dissociation constant is theoretically calculated using the relation; $K_{a, H N O_{2}}(T)=K_{a, H N O_{2}}^{\Theta} \exp \left[-\frac{\Delta H_{a, H N O_{2}}}{R}\left(\frac{1}{T}-\frac{1}{T^{\Theta}}\right)\right]$. 


\section{S3 Activity of photoautotrophs}

\section{S3.1 Photosynthesis and dark respiration}

In the main text, the growth rate of species $i$ with limiting factor $j$ was described as following.

$\mu_{i}(\vec{r}, t)=\mu_{\max , i} f_{T}(\vec{r}, t) f_{p H}(\vec{r}, t) \min \left[f_{i}^{1}(\vec{r}, t), f_{i}^{2}(\vec{r}, t), \cdots, f_{i}^{j}(\vec{r}, t)\right]$,

5 where $\mu_{\max , i}$ is the maximum growth rate of species $i$ with temperature and $\mathrm{pH}$ correction terms, $f_{T}(\vec{r}, t)$ and $f_{p H}(\vec{r}, t)$, respectively. Monod factors are in the minimum function with two types, $f_{i}^{j}=\frac{C_{j}}{K_{S, i}^{j}+C_{j}}$ (when nutrient $j$ is a substrate for the growth) or $f_{i}^{j}=\frac{K_{i, i}^{j}}{K_{i, i}^{j}+C_{j}}$ (when nutrient $j$ is an inhibitor for the growth) based on the stoichiometry for biomass synthesis. For the growth of phototrophs that uses light as an energy source, Monod factor of light intensity was described differently according to the photoacclimation model Bernard (2011).

$f(I(\vec{r}))=\frac{I(\vec{r})}{I(\vec{r})+K_{s, I}+I(\vec{r})^{2} / K_{i, I}}$,

where $I(\vec{r})$ is the light intensity at the position $\vec{r}, K_{s, I}$ is the half-saturation coefficient and $K_{i, I}$ is the inhibition coefficient for light. Light inhibition and acclimation mechanisms for photosynthetic activity are considered unlike the other chemical inhibitors to describe the adaptation of pigment (chlorophyll) synthesis and the reduced yields under strong light as a function of light intensity. During the night, phototrophs maintain their biomass by dark respiration controlled by photo-inhibition term with $K_{I, p h}$. Therefore, the total growth of phototrophic organism is obtained as following:

$$
\begin{aligned}
\mu_{i}^{p} & =\mu_{\mathrm{ph}}+\mu_{\text {respi }} \\
& =\mu_{\max , i} \min \left[f_{i}^{j}, \cdots, f(I(\vec{r}))\right]+\alpha_{r} \mu_{\max , i} \min \left[f_{i}^{j}, \cdots, \frac{K_{I, p h}}{K_{I, p h}+I(\vec{r})}\right] .
\end{aligned}
$$

We note that the maximum respiration rate is linearly proportional to the rate of photosynthesis with the ratio, $\alpha_{r}$ Tillmann and Rick (2001); Wolf et al. (2007). In Figure S1, the normalised growth of photoautotrophs is given as a function of light intensity when the other chemical substances are not limiting. For the light inhibition, $K_{I, p h} \equiv K_{s, I}$ was assumed to describe the activity switch from photosynthetic growth to dark respiration. Under weak light intensity (in a dark environment or deep in the soil domain where light cannot penetrate, i.e. $\left.I(\vec{r}, t)<K_{s, I}\right)$, the dark respiration process is dominant for their growth. During the dark respiration, phototrophs respire like heterotrophic aerobes. The spatio-temporal patterns of phototrophic activity is also depicted in S1. The figure shows the temporal changes in optimal depth of phototrophic activity within the domain.

\section{S3.2 Nitrogen fixation and dynamic yields}

The model includes nitrogen fixation by photoautotrophs (e.g. heterocystous cyanobacteria or other diazotrophic cyanobacteria) to provide a primary source of nitrogen to the biocrust community. While cyanobacteria are oxygenic photosynthetic bacteria, the enzyme nitrogenase for $\mathrm{N}_{2}$ fixation is extremely sensitive to $\mathrm{O}_{2}$. Therefore, cyanobacteria have developed several strategies for this by spatially or temporally separating the photosynthesis and $\mathrm{N}_{2}$ fixation Berman-Frank et al. (2003); Stal (2015). As the 
Light dependency of phototrophic growth

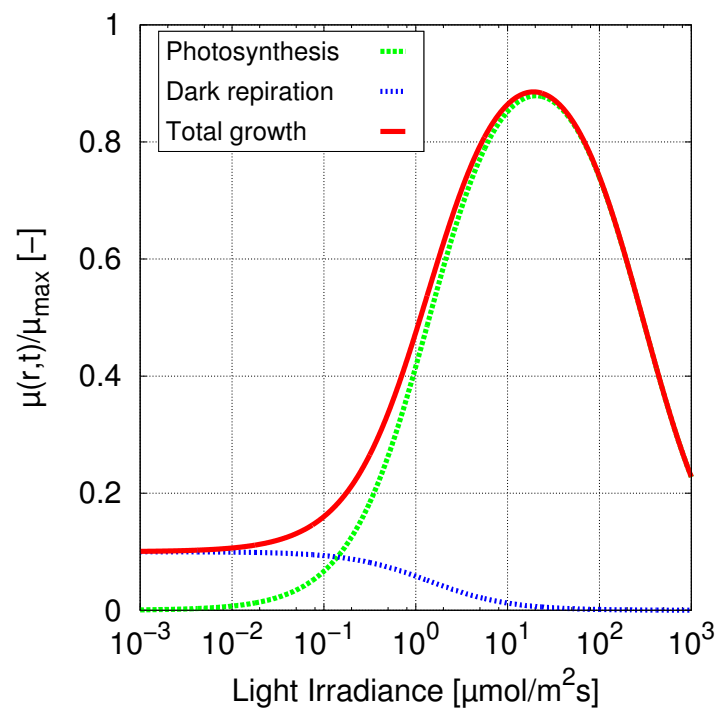

Light irradiance at surface

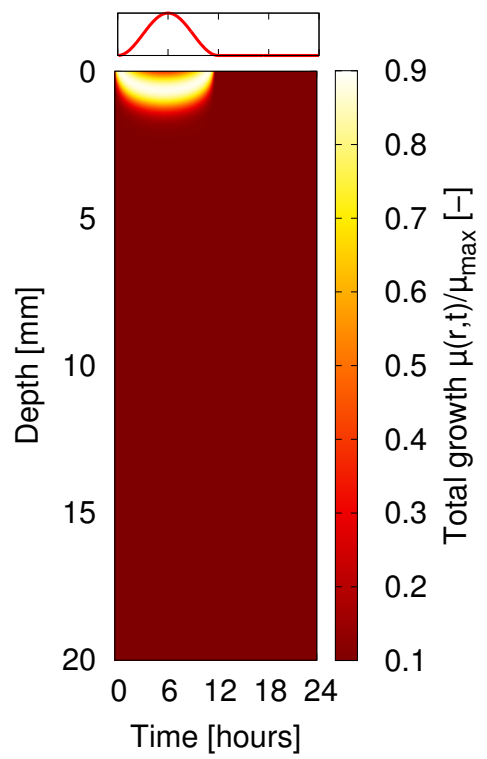

Figure S1. (Left) The activity of photoautotrophs as a function of light intensity in the desert biocrust model when other chemical substances are not limiting. Here, the values are normalised based on the maximum growth rate. The growth of phototrophs is partitioned to two processes, photosynthesis (green dash line) and dark respiration (blue dotted line). When $I \approx K_{s, I}=1.4\left[\mu \mathrm{mol}^{\mathrm{m}} \mathrm{m}^{-2} \mathrm{~s}^{-1}\right]$ (in the figure), phototrophs switches its growth pattern. (Right) Spatio-temporal changes in potential activity of photoautotrophs. Due to the light decay over the depth, the phototrophic activity is localised in top $2 \mathrm{~mm}$. The light inhibition at the strong light intensity results in the diel cycle of optimal depth for photosynthesis.

modelling studies on the nitrogen fixing rate during photosynthesis are very scarce, in this work, we propose a simple relation to couple carbon and nitrogen fixation as a dynamic stoichiometry approach.

For a simplification, photoautotrophs in the model were assumed to be heterocystous cyanobacteria taking the strategy of the spatial separation of heterocysts for $\mathrm{N}_{2}$ fixation within the phototrophic population, which is not explicitly modelled in this study. Instead, by assuming that heterocysts already exist, a certain percentage of energy gain from photosynthesis is assigned for nitrogen fixation to produce ammonium, $\mathrm{NH}_{4}{ }^{+}$. Considering that the heterocysts are located about every tenth cell of a filament, we assume that about 5-15\% of phototrophic biomass will perform $\mathrm{N}_{2}$ fixation while the rests are vegetative cells providing carbohydrates as a source of electrons to heterocysts. As a whole local population (at a patch), the yield of carbohydrates (fixed C) and ammonium (fixed $\mathrm{N}$ ) are determined following the local availability of inorganic $\mathrm{C}$ and $\mathrm{N}$. The basic idea is that when available $\mathrm{C} / \mathrm{N}$ is not balanced for photosynthesis, the net yields of carbohydrates and ammonium are adjusted as a feedback. For instance, during $\mathrm{C}$ and $\mathrm{N}$ fixation by phototrophs that utilises $\mathrm{CO}_{2}$ and $\mathrm{NO}_{3}{ }^{-}$for photosynthesis, 
the net yield of substrate $i$ at time $t, Y_{i, n e t}(t)$, is

$$
\begin{aligned}
\frac{1}{Y_{i, \text { net }}(t)} & =\frac{(1-f(t))}{Y_{i}^{C}}+\frac{f(t)}{Y_{i}^{N}} \\
f(t) & =r_{\mathrm{N}_{2}}\left[1+\frac{1}{2} \tanh \left(1-\frac{Y_{\mathrm{NO}_{3}}-}{Y_{\mathrm{CO}_{2}}} \frac{C_{\mathrm{NO}_{3}}-(t)}{C_{\mathrm{CO}_{2}}(t)}\right)\right]
\end{aligned}
$$

where $Y_{i}^{C}$ and $Y_{i}^{N}$ are the yields of substrate $i$ via photosynthesis (carbon fixation) and $\mathrm{N}_{2}$ fixation, respectively. $r_{\mathrm{N}_{2}}$ is the contribution of heterocysts for the net yield (in this work, $r_{\mathrm{N}_{2}}=0.1(10 \%)$ ). $Y_{\mathrm{NO}_{3}}{ }^{-}\left[\mathrm{g}\right.$ cell/ $\left./ \mathrm{g} \mathrm{NO}_{3}^{-}\right]$and $Y_{\mathrm{CO}_{2}}\left[\mathrm{~g} \mathrm{cell} / \mathrm{g} \mathrm{CO}_{2}\right]$ are yields of biomass during photosynthesis (driven from the stoichiometry), in other words, these yields are the inverses of required amount of inorganic $\mathrm{C}$ and $\mathrm{N}$ in the pore water to synthesise $1 \mathrm{~g}$ of biomass. When the local condition was $\mathrm{N}$ limited, the ratio of available carbon and nitrogen sources, $\frac{C_{\mathrm{NO}_{3}}-(t)}{C_{\mathrm{CO}_{2}}(t)}$, will regulate the energy expenses for $\mathrm{C}$ and $\mathrm{N}$ fixation. Here, a tangent hyperbolic function was chosen as a sigmoid curve with a bound of nitrogen fixation activity between 5-15\% with the

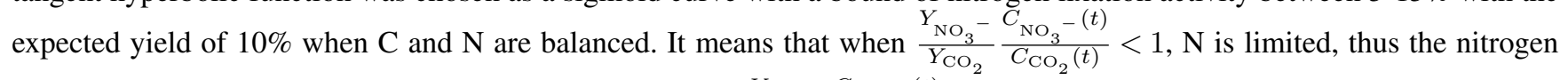
fixation rate increases up to $15 \%$. On the other hand, when $\frac{Y_{\mathrm{NO}_{3}-}-C_{\mathrm{NO}_{3}-}-(t)}{Y_{\mathrm{CO}_{2}}}-\frac{C_{\mathrm{CO}_{2}}(t)}{C^{2}}>\mathrm{N}$ is not limited, thus it decreases to $5 \%$. By using this relation, the net yields of carbohydrates (organic carbon/EPS) and the ammonium are determined based on the local condition as a result of photosynthesis and $\mathrm{N}_{2}$ fixation. This leads to the positive feedback to the community by levelling the unbalanced $\mathrm{C} / \mathrm{N}$ ratio within crusts to maximise the primary productivity. In Figure $\mathrm{S} 2$, the activity of $\mathrm{N}_{2}$ fixation is depicted as a function of $\mathrm{C} / \mathrm{N}$ ratio balance, $\frac{Y_{\mathrm{N}}}{Y_{\mathrm{C}}} \frac{C_{\mathrm{N}}}{C_{\mathrm{C}}}$.

\section{S3.3 EPS production}

Through photosynthesis, photoautotrophs (cyanobacteria) produce EPS increasing the soil carbon pool of biocrusts. The amount of EPS produced by cyanobacteria in drylands varies depending on their environment such as soil types or geological location $\mathrm{Hu}$ et al. (2002). It is challenging to predict and to describe how much and how fast EPS can be produced through microbial activity although it plays the most crucial role in the development of biocrusts (for making extreme environments like a home). It is generally accepted that EPS synthesis in cyanobacterial soil crusts is affected by changes in moisture availability and nitrogen level Mager and Thomas (2011). The most common heterocystous cyanobacteria in biocrusts, Nostoc Bowker et al. (2016), were shown to produce more EPS under unbalanced C/N metabolism Otero and Vincenzini (2004). Moreover, the amount of EPS to cyanobacterial biomass ratio can be increased in the presence of nitrogen source indicating that $\mathrm{N}$ metabolism influences carbohydrate yield Huang et al. (1998). Although evidences show a correlation between carbon fixation/EPS production and nitrogen fixation by heterocystous cyanobacteria, however, it is not straightforward to combine these factors in a simple mathematical model. In this current work, the amount of fixed $\mathrm{C}$ and $\mathrm{N}$ is regulated by the local availability of inorganic $\mathrm{C} / \mathrm{N}$. As we mentioned previously, coupling photosynthesis and $\mathrm{N}_{2}$-fixation allows to obtain the net production of carbohydrates using the dynamic stoichiometry. We assumed that the net production of carbohydrates determines the EPS production together with the local hydration condition. 


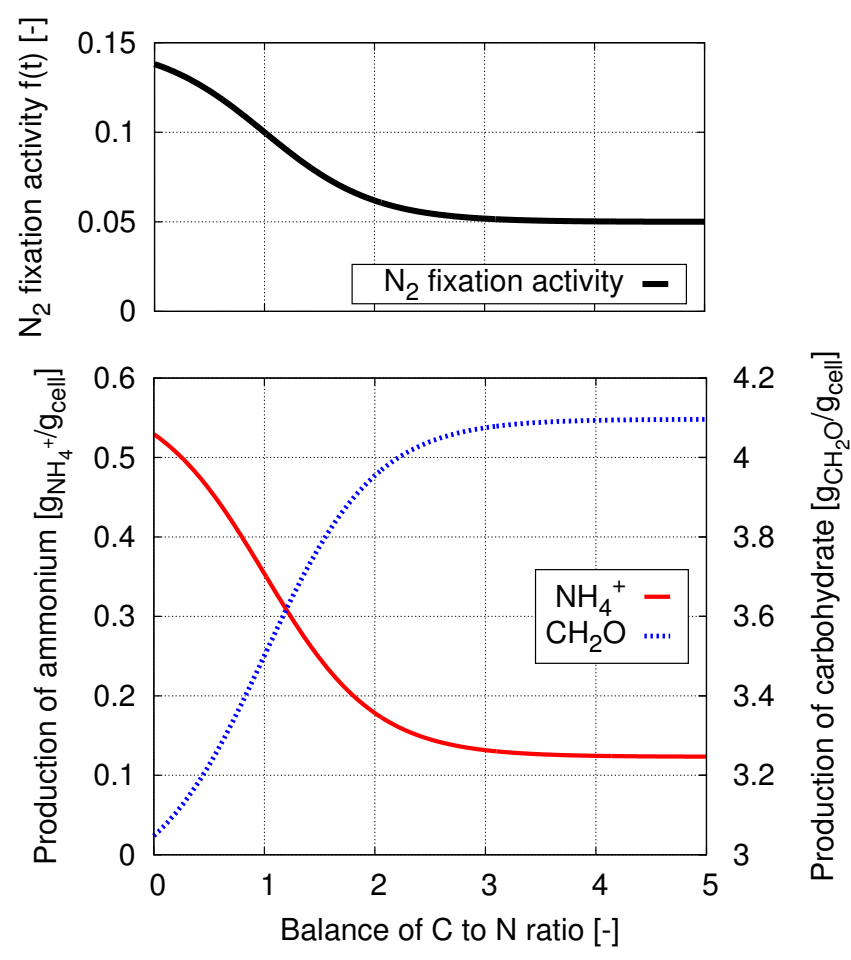

Figure S2. (Top) $\mathrm{N}_{2}$ fixation activity $\left(f(t)\right.$ in Equation (S20)) is depicted as a function of C/N ratio balance, $\frac{Y_{\mathrm{N}}}{Y_{\mathrm{C}}} \frac{C_{\mathrm{N}}}{C_{\mathrm{C}}}$. When the amount of nitrogen is limiting for photosynthesis, the proportion for $\mathrm{N}_{2}$ fixation increases up to $15 \%$. On the other hand, when the amount of carbon is limiting to maximise photosynthesis, $\mathrm{N}_{2}$ fixation proportion decreases to $5 \%$. (Bottom) An example of photosynthesis- $\mathrm{N}_{2}$ fixation regulation. Amounts of produced carbohydrates and ammonium changes depending on the balance of $\mathrm{C} / \mathrm{N}$ ratio according to Equation (S20). In this figure, the amount is given as the inverse of the yield, which is the amount of the product while $1 \mathrm{~g}$ of biomass is synthesised.

When the photosynthetic growth is given as $\mu_{p h}(t)$, Equation (S18), the net production of carbohydrate, $\Delta x_{\mathrm{CH}_{2} \mathrm{O}}$, during $\Delta t$, can be calculated as following.

$\Delta x_{\mathrm{CH}_{2} \mathrm{O}}=\frac{\mu_{p h}(t)}{Y_{\text {net, } \mathrm{CH}_{2} \mathrm{O}}(t)} b(t) \Delta t$

where $\mu_{p h}(t)$ is the photosynthetic growth rate and $b(t)$ is the biomass of a phototrophic cell at time $t$. Here, $Y_{\text {net, } \mathrm{CH}_{2} \mathrm{O}}[\mathrm{g}$ cell $/ \mathrm{g}$

$\left.5 \quad \mathrm{CH}_{2} \mathrm{O}\right]$ is a net yield (from the result of balancing between carbon and nitrogen fixation) representing the amount of synthesised biomass while 1 gram of carbohydrate is produced. The produced carbohydrates are divided into EPS production and organic carbon source that are available for heterotrophs.

Extraceullar carbohydrates produced during photosynthesis contribute to the formation of biopolymeric matrix and some fraction of it might not be bounded to the matrix and released to other heterotrophic organisms as available nutrients. The binding probability of the extracellular carbohydrate residues to the polymeric matrix is written as a function of EPS concentration 

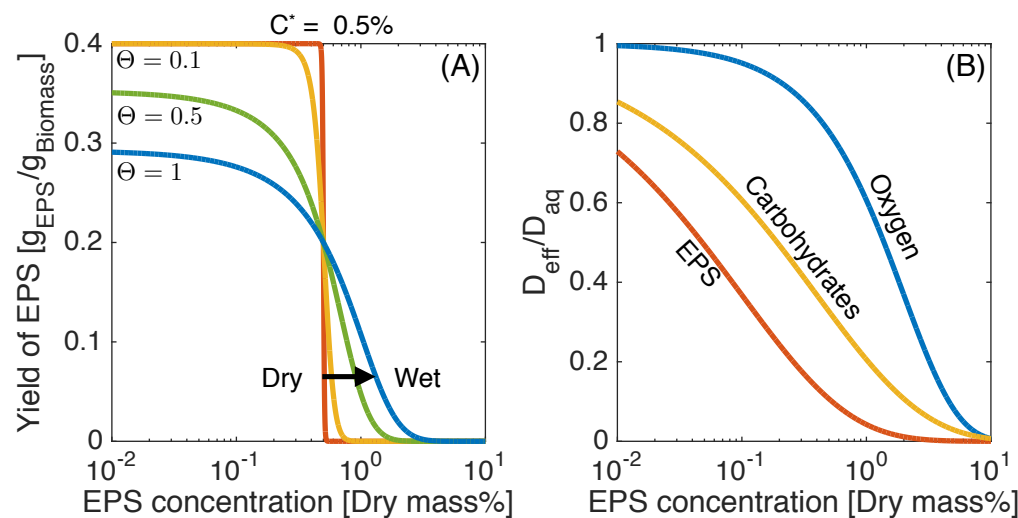

Figure S3. (A) The yield of EPS depends on the local EPS concentration and the hydration condition. When the concentration of EPS is higher than the gelation point $\left(C^{*}=0.5 \%\right.$ in this figure following the gelation point of xanthan Carnali (1991)), the exopolysaccharides secreted by phototrophs will not attach to the biopolymer matix and contributes as readily degradable carbon source for heterotrophs (during night, phototrophs also can utilise this as a source for respiration. (B) Diffusion coefficients of each substrates are determined by the concentration of EPS following Equation (11) in the main text.

$C_{E P S}$, and the saturation degree $\Theta$, in the model:

$f_{p}(C, \Theta)=\frac{1}{e^{-\frac{C_{E P S}-C_{E P S}^{*}}{C_{E P S}^{*} \Theta}+1}}$

where $C_{E P S}^{*}$ is the gelation point for EPS as a polymeric substances. The function describes that residual carbohydrate will not be bounded to the polymeric substances anymore as soon as EPS is in a form of weak-gel (reaching $C_{E P S}^{*}$ ). The degree of polymer binding is regulated by the saturation degree. For example, when the domain is wet, the EPS hydrolysis will lower the binding probability of newly produced residual carbohydates. In Fig. S3 (A), the yield of EPS, $\left(Y_{\text {net, } \mathrm{CH}_{2} \mathrm{O}}-Y_{\text {intracellular, } \mathrm{CH}_{2} \mathrm{O}}\right) f_{p}(C, \Theta)$, that contributes to the polymer matrix is given. $\left(Y_{\text {net, } \mathrm{CH}_{2} \mathrm{O}}-Y_{\text {intracellular, } \mathrm{CH}_{2} \mathrm{O}}\right)\left(1-f_{p}(C, \Theta)\right)$ would be non-bounded organic carbon source that would be available for other organism.

\section{S4 Stoichiometry and rates of biological processes}

10 Stoichiometry relations of microbial processes are given in Table S5. Using the given set of stoichiometries, yields of chemical substances can be obtained for diffusion reaction equations. For instance, the stoichiometry of aerobic heterotrophs in the model is given as following:

$$
1.64 \mathrm{CH}_{2} \mathrm{O}+0.59 \mathrm{O}_{2}+0.20 \mathrm{HCO}_{3}{ }^{-}+0.20 \mathrm{NH}_{4}{ }^{+} \rightarrow \mathrm{CH}_{1.8} \mathrm{O}_{0.5} \mathrm{~N}_{0.2}+1.13 \mathrm{CO}_{2}+0.34 \mathrm{~N}_{2} \mathrm{O}+1.67 \mathrm{H}_{2} \mathrm{O}
$$


In this reaction, heterotrophs use $\mathrm{CH}_{2} \mathrm{O}$ as an electron donor, $\mathrm{O}_{2}$ as an electron acceptor, and $\mathrm{NH}_{4}{ }^{+}$as a nitrogen source for biomass synthesis. As 1.64 mol $\mathrm{CH}_{2} \mathrm{O}$ is required to synthesise $1 \mathrm{~mol} \mathrm{CH}_{1.8} \mathrm{O}_{0.5} \mathrm{~N}_{0.2}$ biomass, it gives the biomass yield.

$Y_{\mathrm{CH}_{2} \mathrm{O}}^{\text {aerobes }}=\frac{1 \mathrm{~mol} \mathrm{CH}_{1.8} \mathrm{O}_{0.5} \mathrm{~N}_{0.2}}{1.64 \mathrm{~mol} \mathrm{CH} \mathrm{CH}_{2} \mathrm{O}}=\frac{24.63 g_{\text {cell }}}{1.64 \times 30.03 g_{\mathrm{CH}_{2} \mathrm{O}}}=0.5\left[g_{\text {cell }} / g_{\mathrm{CH}_{2} \mathrm{O}}\right]$.

All yields of substrates can be calculated in the same manner. The reaction rate expressions for each process correspond to the 5 microbial growth rate, Equation (9) in the main text. Monod parameters, maximum growth rates, half-saturation coefficients, inhibition coefficients are given in Table S6 and detailed descriptions are listed in Table S7. 


\begin{tabular}{|c|c|c|}
\hline microbial group & process & stoichiometry \\
\hline phototroph 1 & photosynthesis & $4.00 \mathrm{CO}_{2}+0.19 \mathrm{NO}_{3}^{-}+4.24 \mathrm{H}_{2} \mathrm{O}+13.9 \mathrm{H}^{+} \rightarrow \mathrm{CH}_{1.6} \mathrm{O}_{0.4} \mathrm{~N}_{0.19}+3.0 \mathrm{CH}_{2} \mathrm{O}+1.0 \mathrm{O}_{2}$ \\
\hline phototroph 2 & photosynthesis & $4.00 \mathrm{CO}_{2}+0.19 \mathrm{NH}_{4}^{+}+4.27 \mathrm{H}_{2} \mathrm{O}+12.0 \mathrm{H}^{+} \rightarrow \mathrm{CH}_{1.6} \mathrm{O}_{0.4} \mathrm{~N}_{0.19}+3.0 \mathrm{CH}_{2} \mathrm{O}+1.0 \mathrm{O}_{2}$ \\
\hline phototroph 3 & photosynthesis & $4.00 \mathrm{HCO}_{3}^{-}+0.19 \mathrm{NO}_{3}^{-}+4.24 \mathrm{H}_{2} \mathrm{O}+17.9 \mathrm{H}^{+} \rightarrow \mathrm{CH}_{1.6} \mathrm{O}_{0.4} \mathrm{~N}_{0.19}+3.0 \mathrm{CH}_{2} \mathrm{O}+1.0 \mathrm{O}_{2}$ \\
\hline phototroph 4 & photosynthesis & $4.00 \mathrm{HCO}_{3}^{-}+0.19 \mathrm{NH}_{4}^{+}+4.27 \mathrm{H}_{2} \mathrm{O}+16.0 \mathrm{H}^{+} \rightarrow \mathrm{CH}_{1.6} \mathrm{O}_{0.4} \mathrm{~N}_{0.19}+3.0 \mathrm{CH}_{2} \mathrm{O}+1.0 \mathrm{O}_{2}$ \\
\hline all phototrophs & $\mathrm{N}_{2}$ fixation* & $5.45 \mathrm{CH}_{2} \mathrm{O}+0.19 \mathrm{HCO}_{3}^{-}+2.93 \mathrm{~N}_{2}+3.66 \mathrm{H}_{2} \mathrm{O}+5.85 \mathrm{H}^{+} \rightarrow \mathrm{CH}_{1.6} \mathrm{O}_{0.4} \mathrm{~N}_{0.19}+5.66 \mathrm{NH}_{4}^{+}+4.64 \mathrm{CO}_{2}$ \\
\hline all phototrophs & dark respiration* & $1.59 \mathrm{CH}_{2} \mathrm{O}+0.54 \mathrm{O}_{2}+0.19 \mathrm{HCO}_{3}^{-}+0.19 \mathrm{NH}_{4}{ }^{+} \rightarrow \mathrm{CH}_{1.6} \mathrm{O}_{0.4} \mathrm{~N}_{0.19}+0.78 \mathrm{CO}_{2}+1.27 \mathrm{H}_{2} \mathrm{O}$ \\
\hline aerobic heterotroph & aerobic respiration* & $1.64 \mathrm{CH}_{2} \mathrm{O}+0.59 \mathrm{O}_{2}+0.20 \mathrm{HCO}_{3}^{-}+0.20 \mathrm{NH}_{4}{ }^{+} \rightarrow \mathrm{CH}_{1.8} \mathrm{O}_{0.5} \mathrm{~N}_{0.2}+1.13 \mathrm{CO}_{2}+0.34 \mathrm{~N}_{2} \mathrm{O}+1.67 \mathrm{H}_{2} \mathrm{O}$ \\
\hline anaerobic heterotroph & denitrification* & $2.13 \mathrm{CH}_{2} \mathrm{O}+0.88 \mathrm{NO}_{3}^{-}+0.88 \mathrm{H}^{+} \rightarrow \mathrm{CH}_{1.8} \mathrm{O}_{0.5} \mathrm{~N}_{0.2}+0.84 \mathrm{CO}_{2}+1.24 \mathrm{H}_{2} \mathrm{O}$ \\
\hline nitrifier 1 (AOB) & ammonium oxidation* & $7.63 \mathrm{O}_{2}+0.80 \mathrm{CO}_{2}+5.99 \mathrm{NH}_{4}^{+} \rightarrow \mathrm{CH}_{1.8} \mathrm{O}_{0.5} \mathrm{~N}_{0.2}+5.79 \mathrm{NO}_{2}^{-}+5.39 \mathrm{H}_{2} \mathrm{O}+11.57 \mathrm{H}^{+}$ \\
\hline nitrifier 2 (NOB) & nitrite oxidation* & $12.77 \mathrm{O}_{2}+1 \mathrm{CO}_{2}+28.44 \mathrm{NO}_{2}^{-}+0.80 \mathrm{H}_{2} \mathrm{O}+0.20 \mathrm{H}^{+} \rightarrow \mathrm{CH}_{1.8} \mathrm{O}_{0.5} \mathrm{~N}_{0.2}+28.25 \mathrm{NO}_{3}^{-}$ \\
\hline
\end{tabular}

Table S5. Stoichiometry of microbial reactions used in the model. The elemental composition of phototrophic biomass is assumed as $\mathrm{CH}_{1.6} \mathrm{O}_{0.4} \mathrm{~N}_{0.19}$ following a reported composition of photoautotrophic bacteria Shastri and Morgan (2005) and the biomass composition of other cells were assumed to be the same as E.coli, $\mathrm{CH}_{1.8} \mathrm{O}_{0.5} \mathrm{~N}_{0.2}$ Grosz and Stephanopoulos (1983). Photosynthesis was simply assumed based on stoichiometry of biomass synthesis from inorganic carbon and nitrogen sources.

${ }^{*}$ MBT-tool (Metabolism based on Thermodynamics) was used to calculate yields of chemical substrates during biomass synthesis Araujo et al. (2016). For all reactions, the energy-transfer-efficiency between catabolism and anabolism was assumed to be 0.5 . 


\begin{tabular}{|c|c|c|c|c|c|c|c|c|c|c|c|}
\hline microbial groups & $\mu_{\max }\left[\mathrm{hr}^{-1}\right]^{a}$ & $m\left[\mathrm{hr}^{-1}\right]^{a}$ & $K^{\mathrm{O}_{2}}$ & $K^{\mathrm{CH}_{2} \mathrm{O}}$ & $K^{\mathrm{CO}_{2}}$ & $K^{\mathrm{HCO}_{3}^{-}}$ & $K^{\mathrm{NH}_{4}{ }^{+}}$ & $K^{\mathrm{NO}_{3}{ }^{-}}$ & $K^{\mathrm{NO}_{2}{ }^{-}}$ & $K^{\mathrm{NH}_{3}}$ & $K^{\mathrm{HNO}_{2}}$ \\
\hline phototroph1 & 1.25 & 0.011 & & & 0.88 & & $0.02^{i h b}$ & 0.0744 & & & \\
\hline phototroph2 & 1.25 & 0.011 & & & 0.88 & & 0.02 & & & & \\
\hline phototroph3 & 1.25 & 0.011 & & & $0.0088^{i h b}$ & 0.88 & $0.02^{i h b}$ & 0.0744 & & & \\
\hline phototroph4 & 1.25 & 0.011 & & & $0.0088^{i h b}$ & 0.88 & 0.02 & & & & \\
\hline all phototrophs (DR) & $0.125^{b}$ & 0.011 & 9.60 & 3.41 & & 0.88 & 0.02 & & & & \\
\hline aerobic heterotroph & 1.25 & 0.05 & $1.248^{c}$ & $0.001^{c}$ & & 0.88 & $1.7 \times 10^{-6}$ & & & & \\
\hline anaerobic heterotroph & 0.20 & 0.05 & $1.248^{i h b, c}$ & $0.001^{c}$ & & & & 0.0022 & & & \\
\hline nitrifier1 (AOB) & 0.2125 & 0.019 & 0.5 & & 0.88 & & 0.90 & & & $8.23^{i n b}$ & $0.03^{i h b}$ \\
\hline nitrifier2 (NOB) & 0.1250 & 0.019 & 0.5 & & 0.88 & & & & 2.96 & $0.0729^{i h b}$ & $0.5036^{i h b}$ \\
\hline
\end{tabular}

Table S6. Monod coefficients used in the model. The maximum growth rates, $\mu_{\max }$ and the maintenance rates, $m$ in the unit of [hr ${ }^{-1}$ ]. Half saturation coefficients, $K_{S}$, and inhibition coefficients, $K_{I}$ are given in the unit of [mg/L]. Inhibition terms are marked with the superscript, $i h b$. Monod coefficients are from the activated sludge model Henze (2000) with phototrophic activity Wolf et al. (2007). The coefficients for ammonia oxidiser (AOB) and nitrite oxidiser (NOB) newly assigned following Blackburne et al. (2007); Park and Bae (2009).

${ }^{a}$ All maximum growth rates are assumed in the model 3 times higher than literature values as the temperature and $\mathrm{pH}$ correction terms reducing the maximum rates.

${ }^{b}$ Dark respiration rate was assigned as $10 \%$ of the maximum growth rate of phototrophs ( $\alpha_{r}=0.1$ in Equation (S18)).

${ }^{c}$ Half-saturation/inhibition for oxygen and polyglucose were modified (higher oxygen inhibition for anaerobes and lower half saturation for sugar for both heterotrophs) to reflect the desert environment adaptation (highly aerated environment with lower carbon contents). 


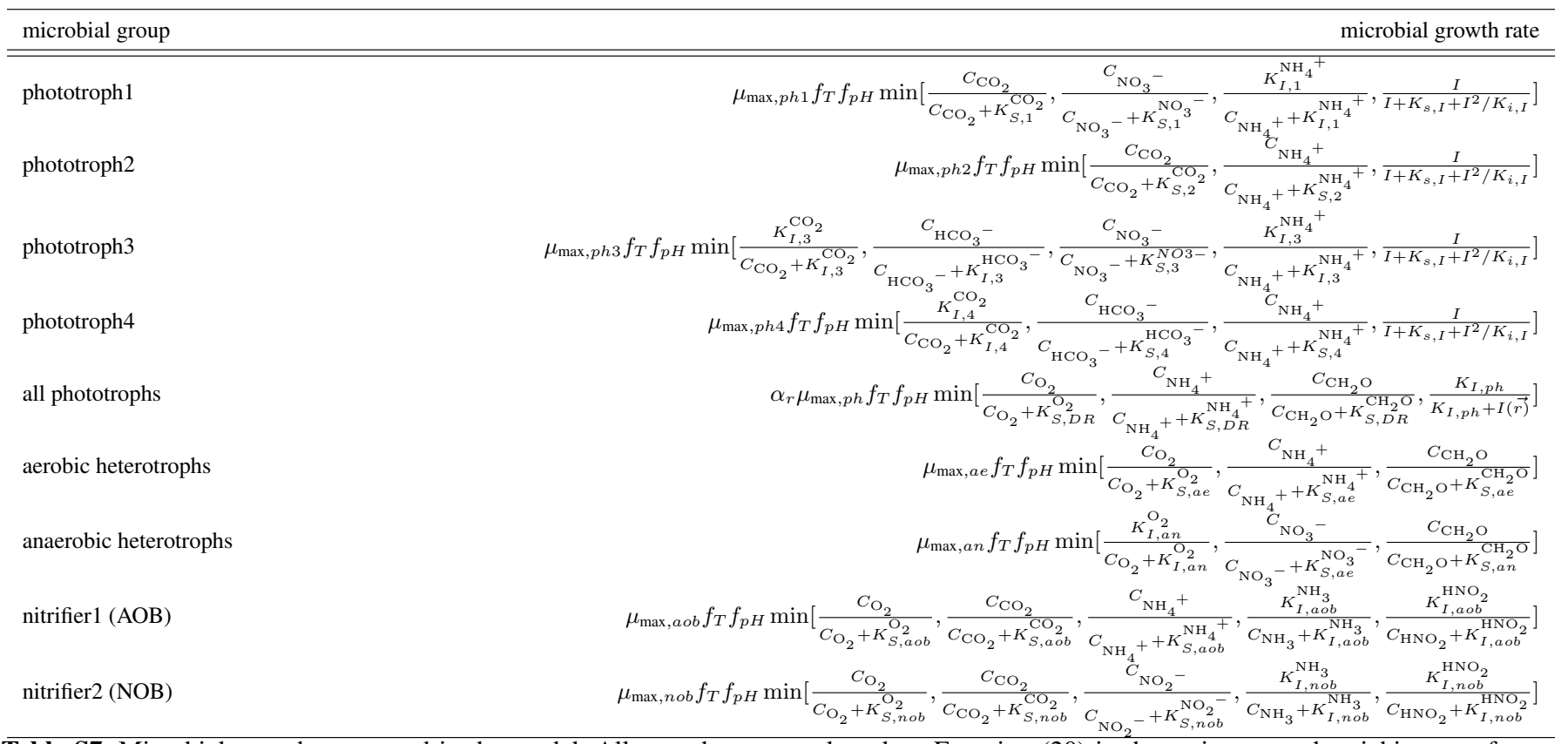

Table S7. Microbial growth rates used in the model. All growth rates are based on Equation (20) in the main text and stoichiometry for biomass synthesis based on their processes (Table S5). Here, $f_{T}=\left[\frac{\frac{T}{T_{\Theta}} e^{\frac{\Delta H_{\Theta}}{R}\left(\frac{1}{T_{\Theta}}-\frac{1}{T}\right)}}{1+e^{\frac{\Delta_{L}}{R}\left(\frac{1}{T_{L}}-\frac{1}{T}\right)_{+e} \frac{\Delta_{H} H}{R}\left(\frac{1}{T_{H}}-\frac{1}{T}\right)}}\right]$ and $f_{p H}=\frac{K_{p H}}{K_{p H}+[H]}$ where $K_{p H}=10^{-5}[M]$, are temperature and $\mathrm{pH}$ correction terms.

\section{S5 Overview of parameters used in this study}

Other parameters used in this study are listed in Table S8 and Table S9. Table S8 summarise control parameters that are environmental specific, such as soil types, light intensity, and soil pH. Other parameters for diffusion and general properties of microbial cells are listed in Table S9. 


\begin{tabular}{|c|c|c|c|c|}
\hline parameter & symbol & value & unit & \\
\hline Parameters for physical domain & & & & Kim and Or (2016) \\
\hline fractal dimension for pore size distribution & $\mathrm{D}$ & 2.65 & {$[-]$} & in this study ${ }^{a}$ \\
\hline mean surface porosity & $\bar{\Phi}$ & 0.6 & {$[-]$} & in this study ${ }^{a}$ \\
\hline mean porosity & $\bar{\phi}$ & 0.4 & {$[-]$} & in this study ${ }^{a}$ \\
\hline size of a patch & $L_{p}$ & 100 & {$[\mu \mathrm{m}]$} & in this study ${ }^{a}$ \\
\hline \multicolumn{5}{|l|}{ Environmental conditions } \\
\hline \multicolumn{5}{|l|}{ Soil chemical property } \\
\hline total amount of $\mathrm{Ca}^{2+}$ in the domain & {$\left[\mathrm{Ca}^{2+}\right]$} & 1.4 & {$[\mathrm{M}]$} & $\mathrm{pH}_{\text {buffer }}^{b}$ \\
\hline total amount of non-reactive ions in the domain & {$[\mathrm{Z}]$} & 1.4 & {$[\mathrm{M}]$} & set point for soil $\mathrm{pH}^{b}$ \\
\hline \multicolumn{5}{|l|}{ Light } \\
\hline maximum light irradiance & $I_{0}$ & 500 & {$\left[\mu \mathrm{mol} / \mathrm{m}^{2} \mathrm{~s}\right]$} & overcast sky $^{c}$ \\
\hline light penetration depth & $\delta_{p}$ & 0.2 & {$[\mathrm{~mm}]$} & rough estimate ${ }^{c}$ \\
\hline \multicolumn{5}{|l|}{ Temperature } \\
\hline average temperature on surface & $\bar{T}$ & 25 & {$\left[{ }^{o} \mathrm{C}\right]$} & moderate temperature (lab) \\
\hline amplitude of temperature cycle & $A_{0}$ & 5 & {$\left[{ }^{\circ} \mathrm{C}\right]$} & in this study \\
\hline
\end{tabular}

environmental conditions.

${ }^{a}$ Property of loamy sand was assumed.

${ }^{b}$ Alkaline soil is assumed to model desert soil. Diffusible calcium ion is assumed to buffer microbial activity and to see the biologically driven calcium carbonate precipitation. Non-diffusing non-reactive ion is applied uniformly in the domain to determine the set point of soil $\mathrm{pH}$.

${ }^{c}$ The typical value of light intensity under overcast sky has been used in this study Garcia-Pichel and Belnap (1996). The penetration depth for the light is roughly estimated from Figure 2 in Garcia-Pichel and Belnap (1996).

\section{S6 Simulated chemical environment of a fully saturated biocrusts}

The chemical dynamics of a fully saturated biocrust differ considerably relative to the more common unsaturated case. A typical results based on dissolved oxygen, $\mathrm{pH}$, total ammonia nitrogen, and nitrate distributions are depicted in Figure S4. The chemical dynamics of a fully saturated biocrust differ considerably relative to the more common unsaturated case. The 5 supersaturation of dissolved oxygen and strong alkalisation within top $2 \mathrm{~mm}$ during daytime is indicative of oxygen production and inorganic carbon uptake during photosynthesis. Below $2 \mathrm{~mm}$, the domain becomes anoxic due to oxygen consumption by aerobic organisms. During nighttime, in the absence of photosynthesis and oxygen production, dark-respiring phototrophs and aerobic organisms rely on diffusing oxygen from atmosphere. In the absence of inorganic carbon consumption at night, the biocrust $\mathrm{pH}$ drops to neutral values near 7 . Total ammonia nitrogen and nitrate show complementary behaviour during day and night, indicating the activity of nitrifiers and denitrifiers. The nitrate level in fully saturated biocrust is about 2 orders of magnitude lower than an unsaturated case, indicating a strong denitrification process. 


\begin{tabular}{|c|c|c|c|c|}
\hline parameter & symbol & value & unit & reference \\
\hline \multicolumn{5}{|l|}{ Parameters for diffusion } \\
\hline diffusion coefficient of $\mathrm{O}_{2}$ & $D_{0}^{\mathrm{O}_{2}}$ & $2 \times 10^{-9}$ & {$\left[\mathrm{~m}^{2} / \mathrm{s}\right]$} & Picioreanu et al. (1997) \\
\hline diffusion coefficient of $\mathrm{CO}_{2}(\mathrm{aq})$ & $D_{0}^{\mathrm{CO}_{2}}$ & $1.91 \times 10^{-9}$ & {$\left[\mathrm{~m}^{2} / \mathrm{s}\right]$} & Ebrahimi et al. (2003) \\
\hline diffusion coefficient of $\mathrm{HCO}_{3}{ }^{-}$ & $D_{0}^{\mathrm{HCO}_{3}{ }^{-}}$ & $1.18 \times 10^{-9}$ & {$\left[\mathrm{~m}^{2} / \mathrm{s}\right]$} & Ebrahimi et al. (2003) \\
\hline diffusion coefficient of $\mathrm{CO}_{3}{ }^{2-}$ & $D_{0}^{\mathrm{CO}_{3}{ }^{2-}}$ & $0.91 \times 10^{-9}$ & {$\left[\mathrm{~m}^{2} / \mathrm{s}\right]$} & Ebrahimi et al. (2003) \\
\hline diffusion coefficient of $\mathrm{NH}_{4}^{+}$ & $D_{0}^{\mathrm{NH}_{4}^{+}}$ & $1.86 \times 10^{-9}$ & {$\left[\mathrm{~m}^{2} / \mathrm{s}\right]$} & Picioreanu et al. (1997) \\
\hline diffusion coefficient of $\mathrm{NH}_{3}$ & $D_{0}^{\mathrm{NH}_{3}}$ & $1.86 \times 10^{-9}$ & {$\left[\mathrm{~m}^{2} / \mathrm{s}\right]$} & same as $D_{0}^{\mathrm{NH}_{4}{ }^{+} a}$ \\
\hline diffusion coefficient of $\mathrm{NO}_{2}^{-}$ & $D_{0}^{\mathrm{NO}_{2}}{ }^{-}$ & $1.9 \times 10^{-9}$ & {$\left[\mathrm{~m}^{2} / \mathrm{s}\right]$} & Hirokawa et al. (2008) \\
\hline diffusion coefficient of $\mathrm{NO}_{3}{ }^{-}$ & $D_{0}^{\mathrm{NO}_{3}{ }^{-}}$ & $1.7 \times 10^{-9}$ & {$\left[\mathrm{~m}^{2} / \mathrm{s}\right]$} & Picioreanu et al. (1997) \\
\hline diffusion coefficient of $\mathrm{HNO}_{2}$ & $D_{0}^{\mathrm{HNO}_{2}}$ & $1.9 \times 10^{-9}$ & {$\left[\mathrm{~m}^{2} / \mathrm{s}\right]$} & same as $D_{0}^{\mathrm{NO}_{2}{ }^{-}}{ }^{a}$ \\
\hline diffusion coefficient of $\mathrm{N}_{2} \mathrm{O}$ & $D_{0}^{\mathrm{N}_{2} \mathrm{O}}$ & $1.84 \times 10^{-9}$ & {$\left[\mathrm{~m}^{2} / \mathrm{s}\right]$} & Tamimi et al. (1994) \\
\hline diffusion coefficient of $\mathrm{CH}_{2} \mathrm{O}$ & $D_{0}^{\mathrm{CH}_{2} \mathrm{O}}$ & $0.6 \times 10^{-9}$ & {$\left[\mathrm{~m}^{2} / \mathrm{s}\right]$} & Stein $(1990)^{b}$ \\
\hline diffusion coefficient of EPS & $D_{0}^{\mathrm{EPS}}$ & $0.12 \times 10^{-9}$ & {$\left[\mathrm{~m}^{2} / \mathrm{s}\right]$} & assumed $^{c}$ \\
\hline diffusion coefficient of $\mathrm{Ca}^{2+}$ & $D_{0}^{\mathrm{Ca}^{2+}}$ & $1.0 \times 10^{-9}$ & {$\left[\mathrm{~m}^{2} / \mathrm{s}\right]$} & Ilie et al. (2012) \\
\hline Parameters for IBM & & & & Kim and Or (2016) \\
\hline median cell volume & $\overline{V_{B}}$ & 4 & {$[\mathrm{fl}]$} & in this work \\
\hline cell volume at division & $V_{\mathrm{B}, \mathrm{d}}$ & $2 \overline{V_{B}} / 1.433$ & {$[\mathrm{fl}]$} & Kreft et al. (1998) \\
\hline minimal active cell volume & $V_{\text {min,d }}$ & $\overline{V_{B}} / 5$ & {$[\mathrm{fl}]$} & Kreft et al. (1998) \\
\hline cell density (dry mass) & $\rho$ & 290 & {$[\mathrm{fg} / \mathrm{fl}]$} & Kreft et al. (1998) \\
\hline size of microbial cells & $R$ & 1 & {$[\mu \mathrm{m}]$} & Kreft et al. (1998) \\
\hline cell velocity at bulk water & $v_{0}$ & 1 & {$[\mu \mathrm{m} / \mathrm{s}]$} & in this work \\
\hline chemotactic sensitivity & $\chi_{0}$ & $3.6 \times 10^{-9}$ & {$\left[\mathrm{~m}^{2} / \mathrm{s}\right]$} & in this work \\
\hline \multicolumn{5}{|l|}{ Other growth related parameters } \\
\hline \multicolumn{5}{|l|}{ Photoacclimation model } \\
\hline half-saturation coefficient for light & $K_{I, I}$ & 1.4 & {$\left[\mu \mathrm{mol} / \mathrm{m}^{2} \mathrm{~s}\right]$} & Bernard (2011) \\
\hline inhibition coefficient for light & $K_{S, I}$ & 295 & {$\left[\mu \mathrm{mol} / \mathrm{m}^{2} \mathrm{~s}\right]$} & Bernard (2011) \\
\hline photo-inhibition for respiration & $K_{I, p h}$ & 1.4 & {$\left[\mu \mathrm{mol} / \mathrm{m}^{2} \mathrm{~s}\right]$} & assumed to be the same as $K_{I, I}$ \\
\hline \multicolumn{5}{|l|}{ Temperature dependent growth rate } \\
\hline enthalpy of activation & $\Delta H_{\Theta}$ & -5.43 & {$[\mathrm{~kJ}]$} & Schoolfield et al. (1981) \\
\hline enthalpy change for inactivation at low $T$ & $\Delta H_{L}$ & -141.1 & {$[\mathrm{~kJ}]$} & Schoolfield et al. (1981) \\
\hline enthalpy change for inactivation at high $T$ & $\Delta H_{H}$ & 687.9 & {$[\mathrm{~kJ}]$} & Schoolfield et al. (1981) \\
\hline low $T$ inactivation & $T_{L}$ & 297.7 & {$[K]$} & Schoolfield et al. (1981) \\
\hline high $T$ inactivation & $T_{H}$ & 314.7 & {$[K]$} & Schoolfield et al. (1981) \\
\hline \multicolumn{5}{|l|}{ Decay of substances } \\
\hline decay rate of the cell lysis (phototrophs) & $k_{d, p h}$ & 0.011 & {$\left[\mathrm{hr}^{-1}\right]$} & assumed \\
\hline decay rate of the cell lysis (other cells) & $k_{d, \text { others }}$ & 0.05 & {$\left[\mathrm{hr}^{-1}\right]$} & assumed \\
\hline EPS degradation rate & $k_{d, E P S}$ & 0.014 & {$\left[\mathrm{hr}^{-1}\right]$} & Wolf et al. (2007) \\
\hline
\end{tabular}

Table S9. Parameters used in the model

${ }^{a}$ The diffusion coefficients were assigned as their pairs for protonation. As the protonation rate is faster than the diffusion processes, the spatial distribution of these species will be mainly determined by local $\mathrm{pH}$ in the model. ${ }^{b}$ Assigned with the diffusion rate of glucose. ${ }^{c}$ Self-diffusion constant of EPS molecule is assigned as $20 \%$ of glucose diffusion. 
(a) $\mathrm{O}_{2}\left[\mathrm{mg} \cdot \mathrm{L}^{-1}\right]$

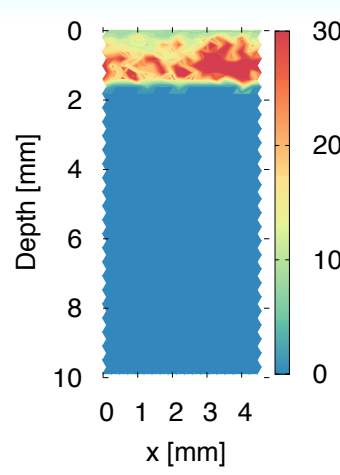

(b) Local pH [-]

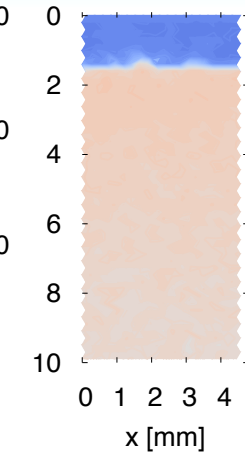

(c) TAN $\left[\mathrm{mg} \cdot \mathrm{L}^{-1}\right]$

(d) $\mathrm{NO}_{3}^{-}\left[\mathrm{mg} \cdot \mathrm{L}^{-1}\right]$

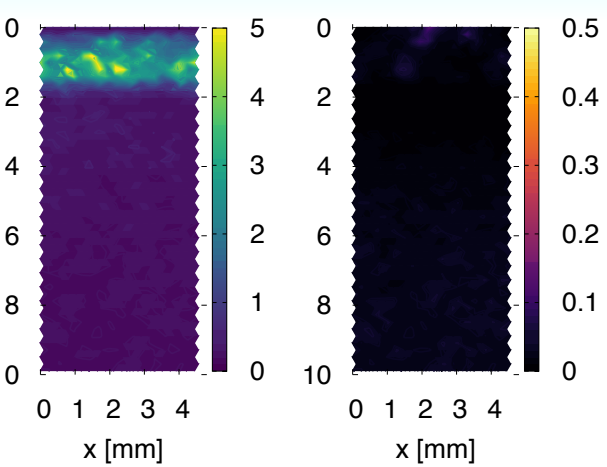

(e) $\mathrm{O}_{2}\left[\mathrm{mg} \cdot \mathrm{L}^{-1}\right]$

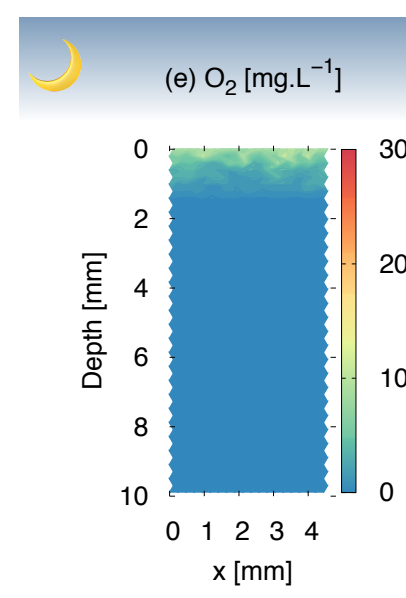

(f) Local pH [-]

(g) TAN $\left[\mathrm{mg} \cdot \mathrm{L}^{-1}\right]$

(h) $\mathrm{NO}_{3}^{-}\left[\mathrm{mg} \cdot \mathrm{L}^{-1}\right]$

0.5
0.4
0.2
0.1
0
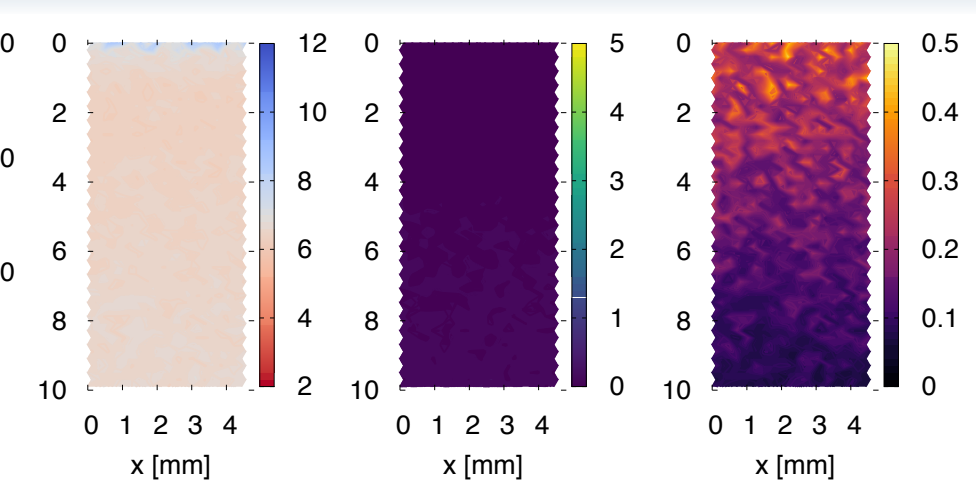

Figure S4. A typical simulated chemical profile within a fully saturated biocrust at midday (top panel) and at midnight (bottom panel). The profiles of dissolved oxygen during day (a) and night (e) are shown. During daytime, top $2 \mathrm{~mm}$ is supersaturated due to photosynthesis, while below $2 \mathrm{~mm}$ becomes anoxic. During night, most of the domain becomes anoxic due to a limited input of oxygen. (b, f) The profile of $\mathrm{pH}$ changes similar to the unsaturated case is shown. During day, top of the crust (within $2 \mathrm{~mm}$ ) exhibits strong alkalisation, marked as blue. During night, $\mathrm{pH}$ at the top crust goes back to the similar level as below $2 \mathrm{~mm}$. (c, g) Total ammonia nitrogen (TAN) increases during daytime on the top of the crust due to microbial production $\left(\mathrm{N}_{2}\right.$ fixation) and the level decreases during nighttime by microbial consumption. Nitrate profile during day (d) and night (h) shows nitrate production occurs mostly during night. The nitrate concentration drops during daytime again due to the consumption by denitrifiers. 


\section{References}

Araujo, P. G., Gras, A., and Ginovart, M.: MbT-Tool: An open-access tool based on Thermodynamic Electron Equivalents Model to obtain microbial-metabolic reactions to be used in biotechnological process, Computational and Structural Biotechnology Journal, 14, 325-332, 2016.

5 Berman-Frank, I., Lundgren, P., and Falkowski, P.: Nitrogen fixation and photosynthetic oxygen evolution in cyanobacteria, Research in Microbiology, 154, 157-164, 2003.

Bernard, O.: Hurdles and challenges for modelling and control of microalgae for $\mathrm{CO}_{2}$ mitigation and biofuel production mitigation and biofuel production, Journal of Process Control, 21, 1378-1389, 2011.

Blackburne, R., Vadivelu, V. M., Yuan, Z., and Keller, J.: Kinetic characterisation of an enriched Nitrospira culture with comparison to Nitrobacter, Water Research, 41, 3033-3042, 2007.

Bowker, M. A., Belnap, J., Büdel, B., Sannier, C., Pietrasiak, N., Eldridge, D. J., and Rivera-Aguilar, V.: Controls on distribution patterns of biological soil crusts at micro to global scales, in: Biological Soil Crusts: An Organizing Principle in Drylands, pp. 173-197, Springer, 2016.

Buhr, H. and Miller, S.: A dynamic model of the high-rate algal-bacterial wastewater treatment pond, Water Research, 17, $29-37,1983$.

Carnali, J.: A dispersed anisotropic phase as the origin of the weak-gel properties of aqueous xanthan gum, Journal of applied polymer science, 43, 929-941, 1991.

Ebrahimi, S., Picioreanu, C., Kleerebezem, R., Heijnen, J., and Van Loosdrecht, M.: Rate-based modelling of $\mathrm{SO}_{2}$ absorption into aqueous $\mathrm{NaHCO}_{3} / \mathrm{Na}_{2} \mathrm{CO}_{3}$ solutions accompanied by the desorption of $\mathrm{CO}_{2}$, Chemical engineering science, 58, 3589-3600, 2003.

Garcia-Pichel, F. and Belnap, J.: Microenvironments and Microscale Productivity of Cyanobacterial Desert Crusts1, Journal of Phycology, 32, 774-782, 1996.

Grosz, R. and Stephanopoulos, G.: Statistical mechanical estimation of the free energy of formation of E. coli biomass for use with macroscopic bioreactor balances, Biotechnology and bioengineering, 25, 2149-2163, 1983.

Henze, M.: Activated Sludge Models ASM1, ASM2, ASM2d and ASM3, vol. 9, IWA Publishing, 2000.

Hirokawa, J., Kato, T., and Mafuné, F.: Uptake of gas-phase nitrous acid by pH-controlled aqueous solution studied by a wetted wall flow tube, The Journal of Physical Chemistry A, 112, 12 143-12 150, 2008.

Hu, C., Liu, Y., Song, L., and Zhang, D.: Effect of desert soil algae on the stabilization of fine sands, Journal of Applied Phycology, 14, 281-292, 2002.

Huang, Z., Liu, Y., Paulsen, B. S., Klaveness, D., et al.: Studies on polysaccharides from three edible species of Nostoc (Cyanobacteria) with different colony morphologies: comparison of monosaccharide compositions and viscosities of polysaccharides from field colonies and suspension cultures, Journal of Phycology, 34, 962-968, 1998.

Ilie, O., van Loosdrecht, M. C., and Picioreanu, C.: Mathematical modelling of tooth demineralisation and pH profiles in dental plaque, Journal of Theoretical Biology, 309, 159-175, 2012.

Kim, M. and Or, D.: Individual-based model of microbial life on hydrated rough soil surfaces, PLoS ONE, 11, e0147 $394,2016$.

Kreft, J.-U., Booth, G., and Wimpenny, J. W.: BacSim, a simulator for individual-based modelling of bacterial colony growth, Microbiology, 144, 3275-3287, 1998.

Mager, D. and Thomas, A.: Extracellular polysaccharides from cyanobacterial soil crusts: A review of their role in dryland soil processes, Journal of Arid Environments, 75, 91-97, 2011. 
Otero, A. and Vincenzini, M.: Nostoc (cyanophyceae) goes nude: extracellular polysaccharides serve as a sink for reducing power under unbalanced C/N metabolism, Journal of Phycology, 40, 74-81, 2004.

Park, S. and Bae, W.: Modeling kinetics of ammonium oxidation and nitrite oxidation under simultaneous inhibition by free ammonia and free nitrous acid, Process Biochemistry, 44, 631-640, 2009.

5 Picioreanu, C., Van Loosdrecht, M., and Heijnen, J.: Modelling the effect of oxygen concentration on nitrite accumulation in a biofilm airlift suspension reactor, Water Science and Technology, 36, 147-156, 1997.

Plummer, L. N. and Busenberg, E.: The solubilities of calcite, aragonite and vaterite in $\mathrm{CO}_{2}-\mathrm{H}_{2} \mathrm{O}$ solutions between 0 and $90^{\circ} \mathrm{C}$, and an evaluation of the aqueous model for the system $\mathrm{CaCO}_{3}-\mathrm{CO}_{2}-\mathrm{H}_{2} \mathrm{O}$, Geochimica et Cosmochimica Acta, 46, 1011-1040, 1982 .

Sander, R.: Compilation of Henry's law constants for inorganic and organic species of potential importance in environmental chemistry, 1999.

Schoolfield, R., Sharpe, P., and Magnuson, C.: Non-linear regression of biological temperature-dependent rate models based on absolute reaction-rate theory, Journal of Theoretical Biology, 88, 719-731, 1981.

Shastri, A. A. and Morgan, J. A.: Flux balance analysis of photoautotrophic metabolism, Biotechnology progress, 21, 1617-1626, 2005.

Stal, L. J.: Nitrogen fixation in cyanobacteria, eLS., 2015.

15 Stein, W.: Channels, Carriers, and Pumps: An Introduction to Membrane Transport Academic Press, New York, 1990.

Su, H., Cheng, Y., Oswald, R., Behrendt, T., Trebs, I., Meixner, F. X., Andreae, M. O., Cheng, P., Zhang, Y., and Pöschl, U.: Soil nitrite as a source of atmospheric HONO and OH radicals, Science, 333, 1616-1618, 2011.

Tamimi, A., Rinker, E. B., and Sandall, O. C.: Diffusion coefficients for hydrogen sulfide, carbon dioxide, and nitrous oxide in water over the temperature range 293-368 K, Journal of Chemical and Engineering data, 39, 330-332, 1994.

20 Tillmann, U. and Rick, H.-J.: Synthesis and New Conception of North Sea Research (SYCON): Working Group 7: Phytoplankton, Zentrum für Meeres-und Klimaforschung, 2001.

Wolf, G., Picioreanu, C., and van Loosdrecht, M.: Kinetic modeling of phototrophic biofilms: The PHOBIA model, Biotechnology and Bioengineering, 97, 1064-1079, 2007.

Yang, A.: Modeling and evaluation of $\mathrm{CO}_{2}$ supply and utilization in algal ponds, Industrial \& Engineering Chemistry Research, 50, 11 18111 192, 2011. 